\title{
THE IMPLEMENTATION OF GOVERNMENT AUTHORITY IN RELATION TO THE SPORTS POLICY OF MALUKU PROVINCE GOVERNMENT
}

\author{
Albertus Fenanlampir*, and Rahmat Hidayat \\ Physical Education, Health and Recreation Study Program \\ Faculty of Education and Teacher Training, Pattimua University, \\ Ambon, Indonesia \\ *email: albertus.fenanlampir17@gmail.com
}

\begin{abstract}
The development of sports in Maluku in its implementation is always based on Law Number 3 of 2005 concerning the National Sports System, that "Local Governments have the authority to regulate, foster, develop, implement, and supervise the implementation of sports in the regions". This means that the government based on institutional functions is given full authority as a policy maker. The purpose of this study is to describe the extent of the Implementation of Government Authority to the Sports System in Maluku Province. The results of the study found: (1) That the sports policy in Maluku has not been a priority in regional development and in its implementation delegated to the relevant agencies / organizations / federations. (2) The role of the Maluku provincial government in sports development is divided into three scopes, namely educational sports, recreational sports and achievement sports. Guidance on recreational sports and educational sports is handled and managed by the Department of Youth and Sports (DISPORA) in coordination with the Department of Education and Culture (DISDIKBUD), the Federation of Indonesian Community Recreational Sports (FORMI) and the National Paralympic Commission (NPC) Maluku to synergize programs from the center to the center to region. Whereas the fostering and development of sports achievements are bestowed and implemented by KONI Maluku and its members. (3) That the Maluku provincial government provides operational assistance with the APBD, through DIPA SKPD and Grants to agencies / organizations / federations namely achievement sports through KONI, Sports education through DISDIKBUD and DISPORA in coordination with FORMI and NPC Maluku. (4) The Government Oversight Function on the implementation of sports in Maluku is carried out in two ways, namely internal and external. Internal supervision is carried out by sports institutions to achieve consistency between policies and implementation, while external supervision by the Inspectorate and the Financial Supervisory Agency (BPK) to ensure the use of the budget is on target and in accordance with reporting.
\end{abstract}

Keywords: implementation, local government authority, maluku sports

\section{Introduction}

Sports is one of the cultural heritages of ancestral activity with deep philosophical values on the meaning of the essence of human life's struggle. True sport is the right of every person as well as the national character building of a nation. Therefore, sport becomes a strategic means to build self-confidence, national identity, and national pride (KONI, 2014).

Law No. 3 of 2005 concerning the National Sports System, Article 12 states that the task of the government both the Central Government and the Regional Government is responsible for the Organization of Sport in determining national sports policies, national sports standards, as well as coordination and supervision of the implementation of national sports.

Received May $10^{\text {th }} 2020$, Revision June $10^{\text {th }} 2020$, Accepted for publication June $18^{\text {th }} 2020$.

Copyright $(2020$ Published by FKIP - Unpatti, ISSN 2721-3110 
Whereas Article 13 states that the Regional Government has the authority to regulate, foster, develop, implement, and supervise the implementation of sports in the regions. The regional government management authority is based on Law No. 23 of 2014 (the results of changes to Law No. 32 of 2004 concerning Regional Government). That is, in the framework of organizing the Sports System in the area of rights and obligations regarding the regulation, guidance, development, implementation, and supervision can be under the control of the Regional Government. That means the Regional Government is like a Central Government based on institutional functions can be interpreted as policy makers.

Regarding sports participation according to the Central Statistics Agency (BPS) in 2012 and published in 2014, it has been shown that of the total 33 Provinces at that time, Maluku Province ranked 26th with a participation rate of only $21.84 \%$ of the population. While the results of the Sport Development Index (SDI) assessment in Maluku, the results of the research of the Unpatti Penjaskesrek academics, are known; The index of participation in sports activities in Maluku averaged 0.316; The open space index used for sports in Maluku averages 0.438; Physical Fitness Index of sports players in Maluku averaged 0.33; The human resource index (trainer, instructor and physical education teacher) in Maluku averages 0.007; and Sports development index in Maluku is in the low category (0.268).

With this minimal participation rate, it turns out that it is synchronous with the role of the local government in Maluku sports development which is also still very minimal. This is proven by several reasons, among others; First, there is no regulation in the form of regional regulations (PERDA) for sports. Second, the lack of attention to the development and development of sports human resources which resulted in a "move" of coaches and potential athletes to other regions. Third, the lack of organizing the Week and Regional sports championships. Fourth, the complexity of the management of sports organizations (the non-existence of sports organizations), and the lack of supervision of the Maluku provincial government.

Moving on from the description that has been stated, the writer is compelled to conduct research related to the Authority of the Maluku Provincial Government in relation to Sports' Policy.

\section{a. The Essence of Government Policy}

As stated in the National Long-Term Development Plan (RPJPN) 2005-2025 that the mission of the National Development 2005-2025 is to "realize a competitive nation" meaning: "to have the ability to compete that is generated through the pattern of coaching and developing actors, power, organizing, funding, training patterns, awards, infrastructure and sports facilities in stages and continuously in accordance with upgrading methods, training, counseling, guidance, correctional, pioneering, research, testing, and competition that has applied management and science and modern sports technology, as well as utilization of aid, and sports centers, in order to achieve maximum results in regional or international competitions "(Kristiyanto, 2016). Therefore, government policy or public policy in principle is made on the basis of broad-based policies. Accordingly, Carl Friederich in Ranjabar (2016) offers a more specific and structured definition of policy by stating that policy is "a series of actions or activities proposed by a person, group, or government in a particular environment, where there are obstacles and opportunities, where the policy is proposed to be useful in overcoming it to achieve goals ".

Thus the policy should be the implementation or implementation of several authorities of a body or a person with their authority on a number of arrangements relating to the public interest as well as exerting influence in it. Hence, the policy is not uncommon sometimes interpreted with public policy. 


\section{b. Local Government Authority in Sports}

Government policy is a formulation of Government decisions that become guidelines for overcoming public problems that have clear objectives, plans and programs to be implemented (Mulyadi, 2015). As a form of social handling and meeting the needs of various interests of citizens, government policies in the field of sports are regulated in Law Number 3 of 2005 concerning the National Sports System (UU SKN). While the extent of autonomy in the regulation of sports legislation in the regions, is regulated in Law Number 23 of 2014 concerning Regional Government (UU PEMDA) and Law Number 12 of 2011 concerning Formation of Legislation (Law P3).

Strengthening this assumption, it is said in article 11 paragraph (1) of the SKN Law that the government and regional governments have the right to direct, guide, assist, and supervise the implementation of sports activities in accordance with statutory regulations. Whereas paragraph (2) confirms that the Government and Regional Governments are obliged to provide services and facilities as well as guarantee the implementation of sports activities for every citizen without discrimination.

Based on the SKN Law, the Central and Regional Governments have the duties, authorities and responsibilities for national sports as referred to in Article 12 to Article 15, including: (1) The Government has the task of establishing and implementing policies and standardization in the sports sector nationally. (2) The Regional Government has the duty to implement policies and coordinate the development and development of sports and carry out standardization in the sports sector in the regions. (3) The Government has the authority to regulate, foster, develop, implement and supervise the implementation of sports nationally. (4) The Regional Government has the authority to regulate, foster, develop, implement and supervise the organization of sports in the regions. (5) The implementation of the task of organizing sports at the national level is carried out in an integrated and continuous manner which is coordinated by the Minister. (6) In carrying out its duties, the Government may delegate part of its authority to the Regional Government in accordance with statutory regulations. (7) In carrying out their duties, the Regional Government shall establish an office which handles the sports sector in accordance with statutory regulations. (8) The Government and Regional Governments are responsible for realizing the objectives of the implementation of national sports.

The implementation of authority in the form of government policy on sports (sport governance) is an effort to motivate and facilitate the community to make sport not only a filler of leisure time but to make sport a lifestyle and achievement sport. In addition to deconcentration or transfer of government affairs based on a number of regulations above, the Regional Government through Government Regulation (PP) Number 16, 17, 18 of 2007 simplifies and clarifies the responsibilities or management of sports by classifying; Sports Organization (PP No. 16/2007), Sports Week and Sports Organization (PP No. 17/2007), and Sports Funding (PP No. 18/2007).

\section{c. Efforts to Implement Government Authority in Regional Sports}

Simplification of government responsibilities including organizing sports, organizing weeks and sports championships, and funding of sports in its implementation is carried out by way of coordination between the person responsible for sports. This includes the government, the Regional Government in this case the regional head together with the local people's representative council (DPRD), related agencies (DISPORA), government extension sports organizations (KONI Province), and the community consisting of elements of academics and sports practitioners.

Based on article 8 of Law No. 25 of 2004 that the stages of the development plan consist of the stages of drafting, stipulating, controlling the implementation, and evaluating the implementation. Furthermore, article 9 states that one of the efforts in the preparation of development plans is through development planning meetings (Musrenbang). One of the 
general objectives of the Musrenbang series is to strengthen development coordination and synergy through a detailed discussion of the implementation framework of the Government Work Plan, namely the regulatory framework, institutional framework and budget framework so that the use of resources efficiently, effectively, fairly and sustainably (BAPENAS, 2016).

\section{Research Method}

\section{a. Approaches and Types of Research}

The approach and type of research used in this study is Qualitative Naturalistic, which by Lincon \& Guba (1985) that qualitative research is not as a method but as an approach. This means that qualitative or naturalistic inquiry research is research conducted in a natural or natural setting.

\section{b. Data Source}

To get data on Provincial Government Policy and Authority, the data sources are the Maluku Regional Secretary, Maluku BAPEDA, Maluku DPRD, Maluku DISPORA, Maluku DISDIKBUD, Maluku KONI, FORMI M and Universities. Data collection techniques used were documentation study, and in-depth interviews.

\section{c. Data Collection Technique}

Data collection in this study, referring to Creswell (2013) is observation, interview, and documentation.

\section{Observation}

Observation according to Marshal (1995) that "through observation of the researcher learn about the behavior and the meaning attached to those behaviors" Through observation, analyze the behavior and meaning of the behavior. From the type of observation, the alternative observation used is observation of participation.

\section{Indepth Interview}

To obtain more complete and detailed data, structured interviews were conducted (Esterberg 2002) of key informants and informants including the Maluku Provincial Regional Secretary, Maluku Provincial Regional Development Planning Board, Maluku Provincial Regional Representative Council (DPRD), Provincial Youth and Sports Agency Maluku, Maluk Province Education and Culture Office, Maluku National Indonesian Sports Committee (KONI), Ambon City Indonesian Sports Federation (FORMI) and Universities.

\section{Documentation}

This documentation in the form of taking pictures in the form of interviews with informants and documents that will be used as completeness of research results.

\section{Research Instruments.}

Because researchers as instruments must be validated in order to know how far researchers are ready to conduct research. This was stated by Corbin \& Strauss (2007) that in qualitative research, researchers in addition to acting as research managers also cannot be replaced by other instruments such as questionnaires. 


\section{d. Data Analysis Technique}

Data analysis techniques used in this study were qualitative data analysis in the form of data reduction, data display, and conclusion drawing / verification.

\section{e. Data Validity}

\section{Credibility}

In order for the research process and results to be accepted or trusted, several criteria need to be carried out, namely; study duration, detailed observation, triangulation, per debriefing, negative case analysis, comparing with other research results, and member check.

\section{Extend the Observation Period (Prolonged engagement)}

For the sake of the validity of the data, the author has extended the observations 2 (two) times, namely from May 8 to July 10, 2018. Within two months it turned out that the data obtained was felt to be insufficient so that the extension of the study was conducted for the second stage for 2 month, from 1 August to 1 October 2018.

\section{Triangulation}

Triangulation is done by triangulation of techniques and data sources. Technical triangulation is done by asking the same thing but with a different technique from the interview, triangulation of sources do by asking the same thing through different sources.

\section{Peer debriefing}

Peer discussion was conducted with sports academics, the Provincial Government bureaucracy to practitioners and sports organizations within the Maluku Provincial Government.

\section{Negative case analysis}

At this stage the researcher finds the data that is opposite so it needs to be verified with several informants until the data becomes compatible.

\section{Member Check}

Testing the credibility of the data by member checking, conducted by researchers by discussing the results of research to data sources that have provided data through discussion. The informants wanted some data to be removed and added to get data certainty.

\section{Transferability}

Transferability is concerned with the question to what stage the results of this study can be applied in other situations so it needs to be detailed, clear, systematic in order to be trusted and can be applied in other social situations.

\section{Dependability}

Dependability testing is done by auditing the entire research process. The audit has been carried out by an independent auditor on all research activities, ranging from determining the problem / focus of research, entering the field, determining the source of data, conducting data analysis, conducting data validity testing to drawing conclusions.

\section{Confirmability}

Testing confirmability means testing the results of research and is associated with the process carried out. Considering the results of the research are a function of the research process carried out, the research has fulfilled the confirmability standard. It is also expected by Creswell (2013) that in research not to the process does not exist but the results are there. 


\section{Result and Discussion}

Data findings and research results regarding the implementation of government authority in relation to the sports policy of the Maluku provincial government, are as follows:

\section{a. Focus I: How is Maluku Provincial Government's Policy towards the Regional Sports System?}

Article 13 paragraph (2) of SKN Law and / or article 11 PP Number 16 Year 2017 concerning Sports Organization states that the regional / provincial government has the authority to regulate, foster, develop, implement, and supervise the implementation of sports in the region / province. If related to article 12 paragraph (2) letter (m) of the Regional Government Law, in its classification it is stated that sports affairs are a compulsory affair of regional governments, of course it is important that the regional government exercise its authority in terms of providing regulatory policies on sports, implementation of development and development sports, organizing activities and or sports championships, as well as supervision of the sports system in the regions.

In establishing sports policies in Maluku, the local government understands that there are links between institutions such as KONI, the Office of Education and Culture (DISDIKBUD), and the Office of Youth and Sports (DISPORA) towards the implementation of sports in the regions. The policy of the Maluku provincial government in the field of sports includes being one of the obligatory affairs of government. The position of sports as a top priority in regional development refers to the 2014-2019 Maluku Province RPJMD, which explains that in the aspect of public services, the sports sector is included in the first focus of compulsory affairs services carried out through the youth and sports sectors that depart from the problem; 1) Sport problems and nurseries are not yet figured out, 2) Limited completeness of sports equipment and not optimal use of sports facilities and infrastructure, and 3) Sports facilities and infrastructure have not been utilized optimally (BAPPEDA Maluku Province, 2014).

Moving on from these problems, in the first point the Maluku provincial government itself determines the critical success factors of the program in the form of youth empowerment programs in certain SKPD and government policies in improving sports performance, then in the second point the determining factor is in the form of facilitation of facilities and adequate and quality infrastructure, and in the third point the factors supporting the success of the program's policy depend on: a) land availability, b) involvement of the private sector, and c) the number of sporting events / activities.

Furthermore, policies in the field of sports have the aim of increasing the expansion and equitable development of education, culture, youth and sports. Whereas the goal is to improve the quality of youth roles and sporting achievements. Thus, the policy strategy designed by the regional government is divided into a strategy to improve sports facilities and infrastructure and a strategy to increase the number and quality of outstanding sportsmen. In the strategy to improve sports facilities and infrastructure, government policy is directed at; 1) encourage the availability of sports facilities and infrastructure in the district / city, and 2) improve the function of existing sports facilities and infrastructure through development and rehabilitation. Whereas in the strategy to increase the number and quality of athletes with achievements, the policy direction consists of: 1) developing and developing sportsmen in a planned, tiered and sustainable manner supported by sports science and technology, and 2) improving management and institutional capacity for sports development and coaching.

Thus identical to Bromley's theory in Mulyadi (2015) that public policy has three different levels based on the policy hierarchy, namely policy level, organizational level, and operational level. The policy level is played by the judiciary and legislature. At this level, there are high institutions or legislatures who are authorized to issue policies 
(regulations) on the widest scale, for example Regional Regulations. Organizational level, played by the executive. Every policy needs to have an arrangement about who is the implementer of a policy, who is responsible for it, who carries out oversight of the policy to be enacted and so on. Operational level, carried out by implementing units such as official or institutional.

\section{b. Focus II: How is the Function of the Coaching and Development of Sports Institutions in Maluku Province?}

The scope of sport basically consists of sports, educational sports achievements, and recreational sports. Achievement Sports is under the control of the Maluku Provincial KONI, while Educational Sports, Recreational Sports and Paralympian sports are under the control of Maluku DISPORA. Related to the tasks and functions of each institution are explained as follows:

DISPORA has the task of assisting the Governor in carrying out regional government affairs in the field of youth and sports, as well as functions in the formulation in the field of youth and sports; implementing technical policies in youth and sports; conducting evaluations and reporting in youth and sports; technical guidance in youth and sports; fostering technical implementing units of services; fostering functional group groups; implementation of administrative services in accordance with the scope of their duties; and the implementation of other functions given by the Governor in relation to their duties and functions (Article 48). Based on this policy DISPORA Maluku Province as an operational level which then carries the mandate to manage educational sports, recreational sports and paralimpian sports, is expected to answer problems in the scope of sport according to its responsibilities while still making the SKN Law as the main guideline for its implementation.

Sports education based on article 1 paragraph 11 of Law Number 3 of 2005 concerning the National Sports System provides an understanding that educational sports are physical education and sports are carried out as part of an orderly and continuing education process to obtain knowledge, personality, skills, health, and fitness physical. Furthermore, in the scope of achievement sports, as a sports committee entrusted by the region to oversee the parent organization of sports branches, in addition to being based on Law Number 3 of 2005, also based on the KONI Statutes and By-Laws, according to its duties, among others, is to assist the government in making policies in the field of management, coaching, and development of achievement sports. While its functions include promoting the achievement of sports promoted by its members to achieve sports performance optimally. (ART / KONI Article 5 paragraph 2-3). Related to this matter, KONI Maluku Province has a work program established through the Provincial Deliberation (MUSPROV) every 4 years and Member Meetings (RAT) every one year. Regarding the strategy of fostering and developing sports achievements in Maluku, according to INF.1 who previously also served as General Secretary of the Maluku Province KONI during the period of 2004-2008, 20082012, "That in my leadership era, coaching towards sports achievement in KONI Maluku consisted from the Maluku Bangun Program in 2004-2008 towards PON XVII East Kalimantan, after that it was followed by the Maluku Medal program in 2008-2012 towards PON XVIII Riau, and the Maluku Achievement Program in 2012-2016 towards PON XIX West Java. Between the Maluku Bangun program and the Maluku Medal Program basically have the same concentration of sub-programs but have different strategies. INF.1 further explained clearly that the implementation of the Maluku Build and Maluku Medals Program included 4 main sub-programs namely; acceleration of coaching towards top athletes, empowering potential trainers, increasing the frequency of competition, and budgeting strategies. If related to the coaching strategy, the Maluku Build Program is fostered focused on the province, while the Maluku Medal Coaching program is directed to the regencies / cities. Another case with the Maluku Achievement Program which has a 
concentration on 6 (six) sub-programs, namely; acceleration of coaching towards top athletes, Participation in pre-PIX XIX Year 2015, Improving the quality of Trainers and Referees, Utilization and procurement of coaching facilities, Increasing the Frequency of competition and Optimizing coaching funds.

What is the attitude of the Government of the Province of Maluku has similarities with the policies defined by Mulyadi (2015) as the formulation of Government decisions that become guidelines for overcoming public problems that have clear objectives, plans and programs to be implemented. Where in order to provide policies on sports in the regions, the problem departs from the not well-divided governmental affairs in government.

In Maluku sport is not yet a priority program in regional development so that coaching is not focused and not well controlled the nature of achievement is very fluctuating and tends to go wrong. Concrete reasons why sports in Maluku have not yet become an important concern of the local government is because until now the management policies for performance management, sports education, and recreational sports in Maluku are still overlapping, fragmented, and running independently. Noting this, the Maluku provincial government should have full authority to provide direction and policies in accordance with the Maluku Provincial Government's Strategic Plan in Sports Development in Maluku.

\section{c. Focus III: How is the role of the Provincial Government in organizing sports in the regions?}

In terms of regulatory policies concerning the regional sports system, research findings prove that the Maluku provincial government has not yet owned or made a regional legal product in the form of a Regional Regulation (PERDA) that specifically regulates the sports system in the regions, except the Governor Regulation (PERGUB) and / or Decree (SK) aimed at dealing with national sport events that are incidental or temporary.

DISPORA as a regional technical institution or agency in charge of the field of sports in the region, claimed that if previously it had tried to have the regional regulation, but due to budget constraints, the consequences of what was to be sought were eventually hampered. Then the regional government from the legislature also felt that the local regulation on sports really needed to be supported, because in addition to increasing the attention of local governments, on the other hand it could also encourage community participation in sports budgeting in the regions so that they would no longer only depend on the regional budget.

Meanwhile, in the content of the idea of sports regulation policies by the regional government, it is important that traditional sports or recreational sports be used as the initial foundation to build the local wisdom of sports in Maluku. The effort is carried out by the regional apparatus agency or DISPORA through collaboration with institutions or federations that are directly responsible for recreational sports and community sports communities or traditional sports, in this case the Federation of Indonesian Community Recreational Sports (FORMI), both through partnership processes and channeling the budget to implement coaching and development program activities.

Unlike recreational sports, educational sports based on article 1 paragraph 11 of Law Number 3 of 2005 concerning the National Sports System provides an understanding that educational sports are physical education and that sports are carried out as part of an orderly and continuing education process to gain knowledge, personality, skills, health and physical fitness. To answer that mandate, the regional government in the context of conducting guidance and development always divides the main tasks and functions of the technical apparatus of the Maluku province through DISDIKBUD and DISPORA.

Discussion about sports education means not just talking about teachers with teaching competencies and training abilities, and students' curricular activities for the development of character education. More than that, to hone and increase the motor potential of students, 
it is necessary to provide guidance to these psychomotor abilities in order to boost student achievement in the field of sports. DISPORA Maluku in taking a coaching role on students through sports facilitates it through the Student Education and Training Center or PPLP. The basic concept of PPLP is that PPLP students practice and live centrally but schools in different places.

PPLP guidance is based on one of the Maluku Province DISPORA missions, which is to achieve outstanding, tiered and sustainable sportsmen. Then the mission was formulated in the form of a motto of "Star in the Field, Champion in Class". So in order to achieve that, in the process of coaching, DISPORA then cooperates with the parents of sports in the PPLP which is entirely funded by the central government. The sports branches consist of Boxing, Athletics, Rowing, Soccer, Karate, and Taekwondo. Systematically, DISPORA also carries out its roles starting from mapping regional potentials, recruiting athletes, implementing training programs, coaching through PPLP, evaluating and relegating athletes, to promoting prospective PPLP athletes who are considered to have the potential to contribute to sports achievements at sporting events such as PPLP National Championship. / D, POPNAS, and its level.

According to Quroni (2012), achievements must be built through a process of coaching and development that is planned, tiered and sustainable with the support of sports science and technology. The role of the Maluku provincial government in the process of fostering and developing performance sports in Maluku is only done in terms of funding or budgeting to sports organizations in the regions. The role of coaching and development in a tiered plan is carried out by KONI which subsequently administers the provincial branch of the sports branches who are members under it adjust their implementation to the program formulated by KONI.

During the service period of the KONI management from 2004 to 2016, the formulation of an achievement sports development program that was conceived and carried out by KONI Maluku consisted of the Maluku Bangun program, Maluku Medal phase I, and Maluku Medal phase II. Coaching aspects generally include accelerating coaching for athletes, empowering coaches, increasing the frequency of competition, and budgeting strategies. Whereas during the 2017-2021 stewardship period, in general the implementation of coaching and development of sports athletes is the responsibility of regional sport administrators that are adjusted to the calendar of the Big Managers of each sport. Meanwhile, KONI Maluku will be responsible for the process of coaching and developing athletes in the sports branch during the Training Center (TC) ahead of PON.

However, both in achievement sports, educational sports and recreational sports, the purpose of organizing sports is intended to equalize and foster development of activities, increase the quality of minimal services, increase effectiveness and efficiency of management, and improve health, happiness, and sports performance (Article 14 paragraph 2 of the Law No. 3 SKN).

\section{d. Focus IV: How is the supervision of the Maluku Provincial Government on the Regional Sports System?}

In revealing how the Maluku Provincial Government oversees the regional sports system, several research findings are described as follows; Regarding supervision of the regional sports system, if referring to the finding data, then there is actually no special institution or body that oversees the problem of sports in the region. However, oversight of the implementation aspect was carried out by the Maluku provincial government again by giving confidence in the form of delegation of authority to government and nongovernment institutions and federations responsible for managing sports in the regions. According to Terry in Widanarto (2012), the existence of supervision allows the 
implementation of work to be observed and managed in accordance with the plan in order to achieve goals.

In accordance with the scope of achievement sports are monitored by KONI, sports education is overseen by DISDIKBUD aimed at teachers (sports personnel) in education and training activities (PPG and PKB) according to the standard implementation of activities, as well as supervision on O2SN that is adjusted to technical guidelines (technical guidelines) implementation O2SN. Then in DISPORA the component supervised in it is aimed at student athletes and PPLP trainers. Supervision of athletes is divided into internal supervision which includes mental control of athletes in the dormitory environment involving officials such as SATPOL PP, and external supervision in the form of coordination with the school to monitor the progress of students who are athletes. Supervision of the trainer is more aimed at his attendance when training along with training programs aimed at PPLP athletes every year. Whereas in recreational sports, although there is cooperation between DISPORA and FORMI in handling recreational sports in the regions, so far there has been no clarity about the form of supervision conducted on recreational sports. However, as a recommendation for supervision in the scope of the sport, important aspects that need to be monitored in its implementation may include recreational sports personnel (trainers, instructors, sports doctors, participants), facilities and infrastructure, coaching programs, and evaluation results on recreational sports for determine the appropriate follow-up.

As a step towards accountability to regional governments, each institution reports to the government in accordance with established mechanisms. Unless FORMI is reporting according to its needs through the fields that overshadow recreational sports at DISPORA. Advanced supervision by the regional government on the regional sports system is carried out by auditing the budget that has been given to each institution through the inspectorate and the BPK. Findings in the form of supervision in the form of violations of the use of the budget will be brought to the legal domain.

Until now, the supervision carried out by the Maluku provincial government on the regional sports system is still weak and not very visible. This is because the supervision that has been carried out so far is still revolving in the form of internal and external audits by the inspectorate and BPK related to the allocation of the budget. In addition, there is no special institution or body that oversees specifically the regional sports system in Maluku.

\section{Conclusion}

a. That the sports policy in Maluku has not yet become a priority in regional development and in its implementation is delegated to the relevant agencies / organizations / federations as an extension of the regional government.

b. The role of the Maluku provincial government in couching and development of sports in the regions is divided into three spheres, namely recreational sports, educational sports and sports achievements. Guidance on recreational sports and educational sports is handled and managed by DISPORA Maluku Province in coordination with DISDIKBUD, FORMI and NPC Maluku to synergize programs from the center to the regions. Whereas the fostering and development of sports achievements are bestowed and implemented by KONI Maluku and its members.

c. That the Maluku provincial government provides operational assistance annually with the Maluku provincial APBD through the DIPA SKPD and Grants to agencies / organizations / federations, namely sports achievements through KONI, Sports education through DISDIKBUD and DISPORA in coordination with FORMI and NPC Maluku.

d. The Maluku Provincial Government's Supervision Function on the implementation of sports in the regions is carried out in two ways, namely internal and external 
supervision. Internal supervision is carried out by sports institutions to achieve consistency between policies and implementation, while external supervision by the Inspectorate and the Financial Supervisory Agency (BPK) to ensure the use of the budget is on target and in accordance with reporting.

\section{References}

Abdurrahman. 2012. Skripsi : Kebijakan Pemerintah Daerah dalam Pelayanan Kesehatan Masyarakat di Kecamatan Bacan Tengah Kabupaten Halmahera Selatan. FISIP Universitas Hasanuddin : Makassar (dipublikasi).

Badan Pusat Statistik. 2016. Statistical Yearbook of Indonesia 2016. CV. Dharma Putra: Jakarta. http://www.bps.go.id

BAPPEDA Provinsi Maluku. 2014. Rencana Pembangunan Jangka Menengah Daerah Provinsi Maluku Tahun 2014-2019. Pemerintah Provinsi Maluku

BAPPENAS. 2016. Panduan Rangkaian Musrenbang Tahun 2016. Kementerian PPN/ BAPPENAS: Jakarta Pusat.

Creswell, J. W. 2013. Research Design: Qualitative, Quantitative, and Mixed Methods Approaches. SAGE Publications, Inc. United Kingdom.

Dae, Adrianus. 2016. Tesis : Kebijakan Pemerintah Daerah tentang Pembinaan Olahraga Pencak Silat di Provinsi Nusa Tenggara Timur (Studi Deskripsi tentang Sumber Daya Manusia, Pendanaan, Sarana dan Prasarana). Prodi IKOR Program Pascasarjana Universitas Sebelas Maret: Surakarta. (dipublikasi).

Deputi Menteri Setneg. 2005. Undang-Undang Nomor 3, Tahun 2005, tentang Sistem Keolahragaan Nasional.

DISPORA Jawa Tengah. 2014. Pedoman Pengembangan Olahraga Unggulan Provinsi Jawa Tengah. DISPORA: Semarang.

Esterberg, K. G. (2002). Qualitative Methods in Social Research. Boston: McGrawHill

JDIH BPK RI. 2014. Peraturan Daerah Provinsi Maluku Nomor 23, Tahun 2014, tentang Pembentukan Organisasi dan Tata Kerja Dinas-Dinas Daerah Provinsi Maluku. http://peraturan.bpk.go.id/Home/Details/31928/ diunduh tanggal 12 Februari 2019.

JDIH Provinsi Maluku. 2016. Peraturan Gubernur Nomor 26, Tahun 2016, tentang Kedudukan, Tugas, dan Fungsi Susunan Organisasi dan Tata Kerja Dinas Daerah Provinsi Maluku. http://jdih.malukuprov.go.id/ peraturan/lihat/af4732711661056 eadbf798ba191272a diunduh pada tanggal 27 Februari 2019.

Joseph, S. Bebeley, etc. all. 2017. Adolescents' Physical Education Literacy Level Due Developmental, Humanistic and Fitness Factors. IOSR Journal of Sports and Physical Education. Vol. 4, Issue 2, Mar-Apr 2017, pp. 15-18.

Kemenkumham RI. 2014. Undang-Undang Nomor 23, Tahun 2014, tentang Pemerintah Daerah.

Kemenpora RI, 2007. Peraturan Pemerintah Nomor 16, Tahun 2007, tentang Penyelenggaraan Keolahragaan.

Kemenpora RI. 2007. Peraturan Pemerintah Nomor 17, Tahun 2007, tentang Penyelenggaraan Pekan dan Kejuaraan Keolahragaan.

Kemenpora RI. 2007. Peraturan Pemerintah Nomor 18, Tahun 2007, tentang Pendanaan Keolahragaan.

Kemenpora \& BPS. 2014. Penyajian Data dan Informasi Kepemudaan dan Keolahragaan 2014. bps.go.id: Jakarta. 
BAPPEDA Provinsi Maluku. 2017. Arah \& Kebijakan Pembangunan Provinsi Maluku Tahun 2018. Pemerintah Provinsi Maluku.

KONI. 2014. Rencana Strategis Komite Olahraga Nasional Indonesia 2014-2018. KONI Pusat: Jakarta.

Kristiyanto, Agus. 2008. Standarisasi Penyelenggaraan Event Olahraga. Makalah di sajikan dalam Seminar Nasional dan Workshop Standar Teknis dan Jasa Event Olahraga Nasional dan Internasional, Hotel Riyadi Palace Solo, 31 Juli s/d 2 Agustus 2008 (dipublikasi)

. 2016. Makalah: Formula Khas Budaya dan Daya Saing Olahraga untuk Bergegas Menuju Pentas Prestasi Dunia (Belajar dari Olimpiade London 2012 dan Rio 2016). disajikan pada sesi pleno seminar nasional "refleksi prestasi dan budaya olahraga dalam perspektif ilmu keolahragaan yang inovatif" di yogyakarta, 31 oktober 2016 (dipublikasi).

Kusumaningrum, A., Dewi. 2015. Modul Manajemen Olahraga dan Rekreasi. https:// rinakurniawati.files.wordpress.com/2013/01/diunduh pada tanggal 11 April 2017.

Lestuny, R. Mega. 2014. Skripsi: Analisis Tindak Tutur Ekspresif Pada Masyarakat Mardika Kota Ambon. Prodi Bahasa dan Sastra Indonesia FKIP UNPATTI : Ambon.

Ma'mun, Amung. 2014. Perspektif Kebijakan Pembangunan Olahraga dalam Era Demokrasi dan Kepemimpinan Nasional di Indonesia. Jurnal Kajian Pendidikan. 4, 131-146.

Marshall, K., White, R., \& Fischer, R. 2007. Conflicts between humans over wildlife management: on the diversity of stakeholder attitudes and implications for conflict management. Biodiversity and Conservation, 16(11), 3129-3146.

Mulyadi, Dedy. 2015. Studi Kebijakan Publik dan Pelayanan Publik. Alfabeta : Bandung.

Quroni, Ahmad. 2012. Makalah: Meneropong Keolahragaan Nasional. https://achmadqurony.files.wordpress.com/2012/03/diunduh pada tanggal 7 April 2017 (dipublikasi).

Rahman, Saiful. 2013. Sistem Penganggaran Pemerintah. http://saifulrahman.lecture.Ub. ac.id/files/201302/Sistem-Penganggaran-Penerintah.pdf/_diunduh pada tanggal 08 Maret 2019.

Ranjabar, Jacobus. 2016. Pengantar Ilmu Politik: Dari Ilmu Politik sampai Politik di Era Global. Alfabeta: Bandung.

Saldana, Johny. 2009. The Coding Manual for Qualitative Researchers. Sage Publications: London.

Samsudin. 2014. Media Pembelajaran Pendidikan Jasmani. PT. Fajar Interpratama Mandiri: Jakarta.

Santosa, Imam, dkk. 2013. Kebijakan Pemerintah tentang Penyediaan Sarana dan Prasarana Olahraga Publik di Kabupaten Kudus (Studi Evaluasi tentang Perencanaan, Ketersediaan, Pemanfaatan, dan Pengelolaan Sarana dan Prasarana Olahraga). Magister Ilmu Keolahragaan Program Pascasarjana UNS: Solo.

Seippel, Ørnulf. 2006. The Meanings of Sport: Fun, Health, Beauty or Community?. Journal of Sport in Society. Vol. 9, No. 1, January 2006, pp. 51-70.

SETNEG RI. 2004. Undang-Undang Nomor 25, Tahun 2004, tentang Sistem Perencanaan Pembangunan Nasional.

Sulaiman, F. King. 2014. Dialektika Pengujian Peraturan Daerah Pasca Otonomi Daerah. Pustaka Pelajar: Yogyakarta.

Suryana. 2010. Metodologi Penelitian: Model Praktis Penelitian Kuantitatif dan Kualitatif. Buku Ajar Perkuliahan. Universitas Pendidikan Indonesia: Bandung. 
Taufiqurokhman. 2014. Kebijakan Publik: Pendelegasian Tanggung Jawab Negara kepada Presiden Selaku Penyelenggara Negara. FISIP Universitas Moestopo Beragama Pers: Jakarta Pusat.

Utama, R. Handika. 2015. Tesis : Kebijakan Pemerintah tentang Pembinaan dan Penyediaan Sarana Prasarana Olahraga Prestasi di Kabupaten Pacitan (Studi Deskriptif tentang Pemassalan, Pembibitan, Pembinaan Prestasi dan Perencanaan, Ketersediaan, Pemanfaatan, Pengelolaan Sarana Prasarana). Program Pascasarjana Universitas Sebelas Maret : Surakarta. (dipublikasi).

Widanarto, Agustinus. 2012. Pengawasan Internal, Pengawasan Eksternal dan Kinerja Pemerintah. Jurnal Ilmu Administrasi Negara, Volume 12, Nomor 1, Juli 2012: 173.

UNESCO Conference of Ministers of Sports and Physical Education. 2004. Developmentof sport in view of IYSPE 2005 in Athens. https://www.un.org/sport2005/ayear/facts. pdf 